\title{
KONCEPTUALIZACJA PRAWDY W ŚWIADOMOŚCI JĘZYKOWEJ POLAKÓW, ROSJAN I NIEMCÓW (PERSPEKTYWA AKSJOLOGICZNA)
}

\author{
THE CONCEPT OF TRUTH IN THE POLISH, RUSSIAN AND GERMAN \\ LINGUISTIC CONSCIOUSNESS \\ (FROM AN AXIOLOGICAL PERSPECTIVE)
}

\author{
BARBARA RODZIEWICZ
}

\begin{abstract}
The present article is an attempt at establishing a way of understanding the term 'truth', as well as characterizing all the phenomena the term encompasses in communities of Polish, Russian and German students. The author analyses the results of a Free Word Association Test.

Barbara Rodziewicz, Uniwersytet Szczeciński, Szczecin - Polska,rodziew@vp.pl
\end{abstract}

Podejmowane przeze mnie rozważania są próbą włączenia się - z perspektywy językoznawcy i humanisty - w dyskusję nad wartościami, ich miejscem i zasadnością bytowania we współczesnym świecie. Celem niniejszej refleksji jest omówienie oraz porównanie sposobów konceptualizacji i wartościowania jednej z nadrzędnych wartości etycznych - prawdy w świadomości językowej młodych Polaków, Rosjan i Niemców, a także ukrytych w słowach prawda, npabda, Wahrheit pojęć - kluczy do określonego kodu kulturowego, który za Wojciechem Chlebdą rozumiem jako „historycznie ukształtowany system znaków, wyobrażeń i przekonań, fundowany przez składniki kultury rodzimej i kultur z nią współfunkcjonujących, system, który, tworząc wspólnotę znaczeń i odwołań, zapewnia poczucie jedności danej społeczności narodowej" 1 . Poznanie owego kodu kulturowego może wydatnie przyczynić się do świadomego nawiązania i podtrzymania dialogu międzykulturowego, zniesienia barier i ułatwienia komunikacji oraz przepływu informacji między jego uczestnikami, co w efekcie umożliwi wzajemne poznanie i zrozumienie.

Prezentowany tu materiał empiryczny stanowi niewielką część obszernego rejestru danych językowych zgromadzonych w rezultacie znanego od czasów Francisa Galtona (1879) eksperymentu lingwalnego, testu asocjacyj-

1 W. C h 1 e b d a, Płaszczyzny oglądu językowego obrazu świata, [w:] Komparacja systemów i funkcjonowania wspótczesnych języków słowiańskich I, red. S. Gajda, Opole 2000, s. 169. 
nego, polegającego na podaniu przez respondenta skojarzenia werbalnego na wyraz hasłowy jakiegoś języka naturalnego, to jest pierwszego słowa lub wyrażenia, które mu przychodzi na myśl po usłyszeniu lub przeczytaniu słowa-bodźca ${ }^{2}$. Testy skojarzeń werbalnych oparte na wspomnianej metodzie stosowane były z powodzeniem od końca XIX wieku i praktykowane są do dzisiaj przede wszystkim przez psychologów (Wundt, Kraepelin, Aschaffenburg, Jung, Kent / Rosanoff) oraz językoznawców i psycholingwistów (Osgood/ Sebeok, Kurcz, Rosenzweig, Moore, Postman, Maršálová, van der Made-van Bekkum, Леонтьев, Уфимцева, Тарасов, Горошко i inni). Dość wcześnie, bo już na początku XX wieku, dowiedziono istnienia sieci werbalnych, wykazując jednocześnie, iż znajdują się one pod dużym wpływem życia społecznego i ekonomicznego oraz przestrzeni kulturowej, w której żyją i której doświadczają użytkownicy danego języka. Zrozumienie i opisanie tych zależności otworzyło perspektywy badań nad świadomością językową, definiowaną jako „całokształt poziomów świadomości, formowanych i uzewnętrznianych za pomocą środków językowych: słów, związków wyrazowych, zdań, tekstów i pól asocjacyjnych" ${ }^{3}$. Zakotwiczone $\mathrm{w}$ świadomości językowej pojęcia nie istnieją samodzielnie, przeciwnie, każde powiązane jest $\mathrm{w}$ dalece uporządkowany, logiczny i uhierarchizowany sposób z szeregiem innych słów i pojęć. Są one z jednej strony częścią osobistego doświadczenia jednostki, efektem jej własnych czynności poznawczych, z drugiej strony - stanowią odzwierciedlenie wiedzy przedmiotowej transmitowanej na różne sposoby przez określoną kulturę i układ społeczny. Testy werbalnych asocjacji, będąc jedną z podstawowych metod badania związków między niematerialną świadomością a materialnym językiem, są funkcjonalnym narzędziem penetracji obszaru intuicyjnej wiedzy na temat otaczającej rzeczywistości, instrumentem pozwalającym wniknąć w kulturowo zakorzenione kategoryzacje oraz aktualizacje pojęć i, co za tym idzie, w różnice pomiędzy kulturami, gdyż, jak trafnie zauważa Edward Sapir, ,język [to] symboliczny przewodnik po kulturze" 4 .

Przeprowadzony przeze mnie eksperyment miał charakter masowy. W teście asocjacyjnym uczestniczyło 1500 osób, po 500 studentów w wieku 18-25 lat, reprezentantów społeczności polsko-, rosyjsko- i niemieckojęzycznej, w równej mierze kobiety i mężczyźni. Dla jego potrzeb skonstruowano ankietę zawierającą dwadzieścia nazw wartości. Materiał uporządkowano losowo. Test miał charakter pisemny. Badani otrzymali dwa zadania.

\footnotetext{
2 Więcej na temat metodologii i wyników badań zob. B. R o d z i e w i c z, Wartości. Polacy - Rosjanie - Niemcy, Szczecin 2014.

${ }^{3}$ Е. Ф. Т а р а с о в, Актуальные проблемы анализа языкового сознания, [w:] Языковое сознание и образ мира, ред. Н. В. Уфимцева, Москва 2000, s. 26.

4 Cyt. za A. W i e r z b i c k ą, Stowa klucze. Różne języki - różne kultury, Warszawa 2007, s. 16.
} 
Zadanie oznaczone numerem jeden polegało na zapisaniu nieukierunkowanej swobodnej reakcji, pierwszego przychodzącego na myśl słowa lub wyrażenia po przeczytaniu wyrazu hasłowego. W drugim zadaniu poprosiłam respondentów o wskazanie wartości, które uważają za najważniejsze w ich życiu i którymi kierują się na co dzień, co pozwoliło ustalić deklarowaną przez nich hierarchię jednostek aksjologicznych. Obok wartości, takich jak patriotyzm, wolność, godność czy sprawiedliwość, na liście słówbodźców znalazło się także referowane tu pojęcie - prawda.

Zagadnienie natury prawdy stanowi jedno z odwiecznych i centralnych pytań $w$ historii rozwoju myśli człowieka. Istotę prawdy zaczęto zgłębiać już w starożytności. Pierwszej próby systematycznej analizy pojęcia prawdy podjął się Arystoteles. Jego klasyczna (zwana również korespondencyjną) definicja prawdy, zawierająca się w krótkim stwierdzeniu "Oto czym jest prawda: styczność z rzeczą i twierdzenie jest prawdą" 5, upatrującym istoty prawdy, najprościej ujmując, w zgodności z rzeczywistością, stała się dominująca nie tylko na przestrzeni dziejów filozofii, ale obowiązuje również $\mathrm{w}$ wielu współczesnych teoriach i dociekaniach odnośnie do prawdy. Wprawdzie z czasem rozwinęły się rozmaite inne podejścia do problemu prawdy, jak choćby konsensualne, koherencyjne, zdroworozsądkowe czy utylitarystyczne ${ }^{6}$, jednak scholastyczna formuła definicyjna „Veritas est adaequatio rei et intellectus" ( $w$ wolnym tłumaczeniu "Odpowiedniość bytu wobec intelektu wyraża prawda")7, którą Tomasz z Akwinu nadał pierwotnemu określeniu Arystotelesa, jest powszechnie znana i uznawana w epistemologii do dziś. Także minimalistyczna definicja prawdy kodowana przez językowe źródła leksykograficzne (między innymi polskie, rosyjskie i niemieckie) wprost nawiązuje do jej klasycznej Arystotelesowskiej wersji.

$Z$ antycznej refleksji filozoficznej wyrosła idea rozumienia prawdy jako bytu aksjotycznego. Prawda, a z nią także dobro i piękno, wcześnie zyskały miano transcendentaliów aksjologicznych, wartości najwyższych, absolutnych, utożsamianych $\mathrm{z}$ bytem idealnym, a więc stricte autotelicznych. Ta tak zwana „Platońska triada wartości” stała się istotnym elementem europejskiej tradycji i $\mathrm{w}$ dalszym rozumieniu również dziedzictwa kulturowego człowieka. Obojętność, odrzucanie lub negowanie znaczenia owych wartości nie tylko dla jednostki, ale także dla wspólnoty długo uchodziły za oznakę jeśli nie swoistego barbarzyństwa, to na pewno nieakceptowanej ignorancji oraz wyjątkowego lekceważenia szczególnego, gdyż usankcjonowanego w długich dziejach myśli ludzkiej, aksjotycznego statusu prawdy, dobra i piękna. Jednakże nastanie epoki ponowoczesności, postulującej

${ }^{5}$ A r y s t o t e l e s, Metafizyka, tłum. K. Leśniak, Warszawa 1983, IX i 1051 b.

6 Por. J. G a l a r o w i c z, Na ścieżkach prawdy, Kraków 1992, s. 193-201.

$7 \mathrm{~T}$ o m a s z z A k w in u, Kwestie dyskutowane o prawdzie, tłum. I. Kuczyński, t. 1, Kęty 1998, s. 17. 
przede wszystkim ludzką jednostkową wolność i subiektywny dobrostan jako wartości nadrzędne, wpłynęło zasadniczo na daleko idącą swobodę w ich wyborze, a niekiedy także i chaos lub wręcz, jak to ujmują niektórzy współcześni badacze-aksjolodzy, "permisywność moralną"8, „kryzys moralności” ${ }^{9}$, „moralną anomię"10. W interesującym mnie tu kontekście słusznie zauważa jeden $\mathrm{z}$ dzisiejszych teoretyków historii idei, autor Historii prawdy, Felipe Fernández-Armesto:

Poszukiwanie prawdy to odwieczne i powszechne dążenie istot ludzkich. Obecnie jednak wielu spośród nas wydaje się z niego w pełni świadomie rezygnować. Podejrzenie, że rzeczywistość jest nierozpoznawalna i niewyrażalna, jest tak samo stare jak dążenie do odkrycia całej prawdy. Ale chyba nigdy nie było poglądem równie szeroko rozpowszechnionym, równie wpływowym i groźnym dla samego pojęcia prawdy, jak w naszych czasach. Na tle dziejów poszukiwania prawdy obecna obojętność wydaje się niespodziewaną, nietypową i niebezpieczną nowością. [...] Zarzucając je, nie mamy pewności, czy posuniemy się choćby o krok dalej, czy w ogóle przetrwamy jako gatunek ${ }^{11}$.

Można dodać, iż w kontekście globalizującego się świata i nieuchronnych przeobrażeń ekonomicznych, politycznych, technologicznych i kulturowych komparatywna diagnoza wartości w ogóle wydaje się tym ciekawsza i istotniejsza, że mamy do czynienia z przejmowaniem norm, wzorów i wartości z zewnątrz, a także z redefiniowaniem podstawowych sposobów postrzegania, kategoryzowania i zwłaszcza etyczno-moralnej oceny świata. Wartości moralne, do których niewątpliwie należy odnieść prawdę, są w opinii nie tylko cytowanego brytyjskiego historyka Fernándeza-Armesto, lecz również wybitnego niemieckiego fenomenologa i aksjologa Dietricha von Hildebranda „węzłowym problemem świata” 12, zaś ich brak ,jest największym złem"13.

8 A. J a s i ń s k a - K a n i a, Między rygoryzmem a permisywnością. Przemiany moralności w Polsce i w Europie, [w:] Wartości i zmiany. Przemiany postaw Polaków w jednoczacej sie Europie, red. A. Jasińska-Kania, Warszawa 2012, s. 106.

${ }^{9}$ A. J a s i ń s k a - K a n i a, Indywidualizacja i uspołecznienie: przeksztatcenia moralności w Polsce i w Europie, [w:] Polacy wśród Europejczyków, red. A. Jasińska-Kania i M. Marody, Warszawa 2002, s. 212.

${ }^{10} \mathrm{H}$. Ś w i d a - Z i e m b a, Niektóre symptomy anomii moralnej społeczeństwa polskiego, „Nauka” 2010, nr 3, s. 68-73.

${ }^{11}$ F. F e r n á n d e z - A r m e s t o, Historia prawdy, przeł. J. Ruszkowski, Poznań 1997, s. 10.

12 D. H i 1 d e b r a n d, Fundamentalne postawy moralne, tłum. E. Seredyńska, [w:] Wobec wartości, red. D. Hildebrand, J. A. Kłoczowski, J. Paściak, J. Tischner, Poznań 1982, s. 10.

13 Ibidem. 
Czym jest zatem prawda utrwalona $\mathrm{w}$ świadomości językowej przedstawicieli trzech etnicznie zróżnicowanych sąsiadujących kultur? Przejdę do wyników testu werbalnych asocjacji i przeanalizuję strukturę sieci skojarzeniowej powstałej wokół słów-bodźców PRAWDA / ПРАВДА / WAHRHEIT.

Pozyskany materiał badawczy to 486 nieukierunkowanych swobodnych reakcji - skojarzeń na przytoczone wyrazy hasłowe: 157 asocjatów polskojęzycznych, 151 asocjatów rosyjskojęzycznych i 178 asocjatów niemieckojęzycznych. Jedną $\mathrm{z}$ wiodących konstytuent profilu asocjacyjnego prawdy we wszystkich poddanych analizie językach są skojarzenia werbalizujące pojęcia przeciwstawne względem słów-bodźców. Ilustruje je w sumie 90 odpowiedzi rosyjskojęzycznych, tj. 18\% ogółu skojarzeń, oraz po 86 ujęzykowień niemiecko- i polskojęzycznych, tj. po $17,2 \%$ werbalizacji, por. np.: asocjaty w języku polskim - kłamstwo (48 wskazań - 9,6\%), fatsz (36 wskazań $-7,2 \%)$, brak kłamstwa (1 reakcja $-0,2 \%$ ); asocjaty w języku rosyjskim - ложь (81 wskazań - 16,2\%), вранъё (2 reakcje - 0,4\%), нет ıжи (2 reakcje - 0,4\%); asocjaty w języku niemieckim - Lüge (82 wskazań - 16,4\%), keine Lügen (1 reakcja - 0,2\%), Lügen (1 reakcja - 0,2\%). Reakcje wyrażające binarną opozycję semiotyczną "prawda - kłamstwo" należałoby zinterpretować jako przejaw reprezentatywnego myślenia i doświadczenia człowieka - przedstawiciela gatunku, a nie konkretnej nacji. Jak objaśnia Булат Ганеев, analizujący zjawisko antynomii w języku i mowie, odwołując się do szeregu filozoficznych, socjologicznych i lingwistycznych koncepcji dychotomicznej natury świata i jego elementów,

\footnotetext{
Ментальный мир - это сфера действия противоречий. [...] Любое мышление начинается с отрицания, так как человек изначально противопоставляет свое „Я” миру, который для него „Не-ЯІ”, и только после этого субъект начинает членить мир на остальные его составляющие ${ }^{14}$.
}

Zjawisko to standaryzują wysoce skonwencjonalizowane formacje językowe, rejestrujące nie tylko wspólną dla danej społeczności i spójną kulturowo praktykę, ale także doświadczenia człowieka w ogóle, mianowicie paremie, por. np.: Kłamstwo przeminie, prawda nie zginie, Lepsza gorzka prawda niż słodkie kłamstwo; Правда одна, а лжи сколько угодно, Правда стара, да не умирает, ложь помоложе, да недолго поживает; Wer einmal lügt, dem glaubt man nicht, und wenn er auch die Wahrheit spricht, Die Wahrheit bedarf nicht viel Worte, die Lüge kann nie genug haben.

Dużo miejsca w strukturze sieci skojarzeniowych powstałych wokół referowanego pojęcia zajmują także odpowiedzi stanowiące uzupełnienie wspomnianych asocjatów standaryzowanych przez dane systemowe analizowanych języków. Są to zarówno transmitowane przez słowniki cechy

${ }^{14}$ Б. Г а н е е в, Противоречия 8 языке и речи, Уфа 2004, s. 67, 71. 
definicyjne prawdy, wyrażone implicite lub explicite, jak również bardzo licznie przytaczane synonimy, por. np.:

- skojarzenia polskojęzyczne: fakt (3 reakcje - 0,6\%), fakty (1 reakcja - 0,2\%), zgodność (3 reakcje - 0,6\%); szczerość (86 wskazań - 17,2\%);

- skojarzenia rosyjskojęzyczne: Верность (1 reakcja - 0,2\%), утверждение факта (1 reakcja - 0,2\%), фракт (1 reakcja - 0,2\%); честность (65 wskazań - 13\%), истина (22 wskazania - 4,4\%), искренность (18 wskazań - 3,6\%), открытость (9 wskazań - 1,8\%);

- skojarzenia niemieckojęzyczne: Tatsache (3 reakcje - 0,6\%), Sachverhalten (2 reakcje - 0,4\%); Ehrlichkeit (73 wskazania - 14,6\%), ehrlich (10 wskazań - 2\%), Offenheit (10 wskazań - 2\%), Aufrichtigkeit (8 reakcji - 1,6\%).

Wspomniane ujęzykowienia stanowią 19,8\% odpowiedzi polskojęzycznych, $24,6 \%$ odpowiedzi w języku rosyjskim i $22,4 \%$ odpowiedzi udzielonych przez ankietowanych Niemców.

Ciekawie rysują się pozaleksykalne, kulturowo uwarunkowane składniki asocjacyjnego profilu prawdy. Prawda jest wartością uwarunkowaną i ugruntowaną wspólnotowo. Wywodząca się z tradycji klasycznej (oraz ukształtowana ostatecznie na gruncie chrześcijaństwa) intersubiektywność (dialogiczność) prawdy przejawia się w szeregu reakcji wskazujących jednoznacznie na społeczną, nie jednostkową proweniencję rozumienia tego pojęcia. Prawda w tym ujęciu jest swoiście pojmowaną powinnością, imperatywem, gdyż warunkuje inter- i intrapersonalne porozumienie i zgodną koegzystencję. Szczególnej roli prawdy intersubiektywnej ankietowani doszukują się $\mathrm{w}$ opartych na silnych więziach emocjonalnych relacjach $\mathrm{z}$ bliskim i najbliższym otoczeniem społecznym, por. np.:

- odpowiedzi w języku polskim: człowiek (2 reakcje - 0,4\%), relacje $z$ innymi ludźmi (1 reakcja - 0,2\%); miłość (2 reakcje - 0,4\%), uczucie (2 reakcje $-0,4 \%)$, zwiazek (2 reakcje $-0,4 \%)$, związek kochajacych się osób (1 reakcja $-0,2 \%)$; przyjaciel (3 reakcje $-0,6 \%)$, przyjaźn ( 2 reakcje $-0,4 \%)$; rodzina (3 reakcje - 0,6\%), dom (2 reakcje - 0,4\%), dziadek (1 reakcja - $0,2 \%)$, matżeństwo (1 reakcja - 0,2\%), mama (1 reakcja $-0,2 \%)$, rodzice (1 reakcja - 0,2\%);

- odpowiedzi w języku rosyjskim: взаимопонимание (1 reakcja - 0,2\%); друг (3 reakcje $-0,6 \%)$, друзъя (1 reakcja $-0,2 \%)$; мама $(3$ reakcje $-0,6 \%)$, мать (1 reakcja $-0,2 \%)$; юбовь (1 reakcja $-0,2 \%)$, муж (1 reakcja $-0,2 \%)$, партнерские отношения (1 reakcja $-0,2 \%$ );

- odpowiedzi w języku niemieckim: Gemeinschaft (1 reakcja - 0,2\%), Zwischenmenschliches (1 reakcja - 0,2\%); Liebe (2 reakcje - 0,4\%), Partnerschaft (2 reakcje - 0,4\%), Basis einer jeden Beziehung (1 reakcja - 0,2\%), Basis für Beziehung (1 reakcja - 0,2\%), Beziehung (1 reakcja - 0,2\%), Beziehungen (1 reakcja $-0,2 \%)$, Partner (1 reakcja - 0,2\%), Partnerin (1 reakcja - 0,2\%); mein Vater (1 reakcja - 0,2\%); Freundschaft (13 wskazań - 2,6\%), Freunde (6 reakcji $-1,2 \%)$, Freund (1 reakcja $-0,2 \%$ ). 
Pośrednio do powyżej wspomnianego wymiaru prawdy odnoszą się również reakcje wyrażone słowami - polskim zaufanie (12 wskazań - 2,4\%), rosyjskimi доверие (36 wskazań - 7,2\%), уважение (4 reakcje - 0,8\%) i niemieckim Vertrauen (16 wskazań - 3,2\%) - a priori implikującymi obecność interlokutora. Asocjaty odnośnie do dialogicznego pojmowania prawdy silnie zakotwiczone są w świadomości językowej rosyjsko- i niemieckojęzycznych uczestników eksperymentu - odpowiednio 10,6\% i 10\% ujęzykowień, nieco rzadziej na intersubiektywność prawdy wskazują Polacy (7,8\% werbalizacji).

Dalsza analiza profilu skojarzeniowego prawdy ujawnia, że jest to w mniemaniu respondentów pojęcie wyjątkowo narażone na użycia manipulacyjne. Już, nota bene, w filozofii starożytnej, obok koncepcji prawdy jako bytu idealnego, prawdy pojmowanej jako najwyższa wartość (Platon, Arystoteles), a więc teorii akcentującej bezinteresowność dążenia do prawdy, zaczęto rozwijać idee prawdy o charakterze dynamicznym, prawdy praktycznej, wysuwając tym samym tezę o braku prawdy powszechnej (sofiści). Sceptycyzm w odniesieniu do prawdy, jej utylitarny charakter i pragmatyzm szczególnie silnie zaznacza się w epoce nowożytnej (Dewey, Nietsche). Tę subiektywną, ulotną i relatywną naturę prawdy zauważa niewielu respondentów polsko- i rosyjskojęzycznych (odpowiednio 1\% i $4 \%$ werbalizacji). Przekonanie o względności i użyteczności prawdy najsilniej utrwaliło się w mentalnych strukturach ankietowanych Niemców (ogółem aż $14,2 \%$ asocjatów), por. np.:

- asocjaty polskojęzyczne: jest względna (1 reakcja - 0,2\%), nie ma jednej (1 reakcja $-0,2 \%)$, relatywna (1 reakcja $-0,2 \%)$, względna sprawa (1 reakcja $-0,2 \%)$, wybór (1 reakcja $-0,2 \%)$;

- asocjaty rosyjskojęzyczne: y каждого своя (7 reakcji - 1,4\%), интерпретация (1 reakcja - 0,2\%), кому и для чего (1 reakcja - 0,2\%), никогда не бывает одна (1 reakcja - 0,2\%), относительна (1 reakcja - 0,2\%), полуправда (1 reakcja - 0,2\%), разная (1 reakcja - 0,2\%), субъективна (1 reakcja - 0,2\%), субъективное суждение (1 reakcja - 0,2\%), тактичность (1 reakcja $-0,2 \%)$;

- asocjaty niemieckojęzyczne: subjektiv (31 wskazań - 6,2\%), relativ (24 wskazania $-4,8 \%$ ), es gibt viele Wahrheiten ( 2 reakcje $-0,4 \%)$, biegsam (1 reakcja $-0,2 \%)$, dehnbar (1 reakcja $-0,2 \%$ ), die halbe Wahrheit (1 reakcja $-0,2 \%)$, individuell $(1$ reakcja $-0,2 \%)$, ist relativ ( 1 reakcja $-0,2 \%)$, nicht immer die beste Lösung (1 reakcja - 0,2\%), Methodenlehre (1 reakcja - 0,2\%), reflexives Denken (1 reakcja - 0,2\%), verschweigt man manchmal besser (1 reakcja $-0,2 \%)$, wenn nötig (1 reakcja $-0,2 \%$ ).

Wśród respondentów reprezentujących odmienne kultury nie ma pełnej zgodności odnośnie do sprecyzowania „nośników” prawdy. Dla Polaków będzie to przede wszystkim instytucja sądownictwa w ogóle oraz reprezen- 
tujące ją osoby, por.: sąd (17 wskazań $-3,4 \%$ ), sędzia (2 reakcje $-0,4 \%$ ); prawo, sady (1 reakcja - 0,2\%). Pogląd ten wyraża $4 \%$ badanych. Niemcy wiążą prawdę $\mathrm{z}$ nauką i wiedzą oraz dzieckiem ( $2 \%$ odpowiedzi), por.: Wissenschaft (6 reakcji - 1\%), Wissen (3 reakcje - 0,6\%), Wissen(schaft) ( 1 reakcja $-0,2 \%)$, Kind (5 reakcji $-1 \%)$, Kinder (1 reakcja - 0,2\%). Rosjanie przywołują słowo русская (4 reakcje - 0,8\%), implicytnie wskazując na związek prawdy i prawa (reguł), oraz, podobnie jak ich zachodnioeuropejscy rówieśnicy, odwołują się do prawdomówności dziecka, ребёнок (5 reakcji - 0,6\%). Tylko Polacy $(1,4 \%$ werbalizacji) i zwłaszcza Rosjanie (3,2\% ujęzykowień) wskazują w omawianym kontekście na egzystencjalny wymiar prawdy, autentyczność bytu człowieka, por.: odpowiedzi w języku polskim - życie (6 reakcji - 1,2\%), życie ludzkie (1 reakcja - 0,2\%); odpowiedzi w języku rosyjskim - жизнь (9 wskazań - 1,8\%), жизни (5 reakcji - 1\%), о жизни (1 reakcja - 0,2\%), это жизнь (1 reakcja - 0,2\%).

Prawda zyskuje aksjotyczne nacechowanie poprzez sytuowanie jej na równi z szeregiem innych wartości, w tym również transcendentaliów. Polacy, dla których ta pośrednia aksjologizacja stanowi istotną konceptualizacyjną część profilu skojarzeniowego prawdy, odwołują się najczęściej do uczciwości, dobra i sprawiedliwości - uczciwość (65 wskazań - 13\%), dobro (13 wskazań - 2,6\%), sprawiedliwość (10 wskazań - 2\%), sprawiedliwy (1 reakcja - 0,2\%). W odpowiedziach rosyjskojęzycznych wartością utożsamianą z prawdą jest sprawiedliwość - сnравеdливость (12 wskazań - 2,4\%). Młodzi Niemcy akcydentalnie wiążą prawdę również ze sprawiedliwością - gerecht (1 reakcja - 0,2\%), Gerechtigkeit (1 reakcja - 0,2\%), co odpowiada rozwijanej w filozofii koncepcji sprawiedliwości jako prawdy wobec drugiego człowieka, uznania i poszanowania jego godności. Stanowisko takie podziela między innymi współczesny włoski filozof moralny Vittorio Possenti ${ }^{15}$. W świadomości językowej pojedynczych uczestników testu prawda koresponduje także z innymi wartościami (przede wszystkim etycznymi), co ilustrują przykładowe reakcje:

- w języku polskim: godność (2 reakcje - 0,4\%), lojalność (2 reakcje $-0,4 \%)$, moralność $(2$ reakcje $-0,4 \%)$, honor $(1$ reakcja $-0,2 \%)$;

$-\mathrm{w}$ języku rosyjskim: честь (3 reakcje $-0,6 \%$ ), добросовестность (1 reakcja - 0,2\%);

- w języku niemieckim: Achtung (1 reakcja - 0,2\%), Schönheit (1 reakcja $-0,2 \%)$, Weisheit (1 reakcja $-0,2 \%)$, Würde (1 reakcja $-0,2 \%)$.

Prawda nie jest badanym obojętna. Prawdomówność, jak zauważają nieliczni ankietowani, wymaga wprawdzie odwagi i bywa wyzwaniem - por. takie reakcje jak: odwaga (2 reakcje - 0,4\%), trud (1 reakcja - 0,2\%),

${ }^{15} \mathrm{H}$. R a r o t, Sprawiedliwość jako prawda, [w:] Czy sprawiedliwość jest możliwa?, pod red. D. Probuckiej, Kraków 2008, s. 103. 
wyzwanie (1 reakcja - 0,2\%); смелость (1 reakcja - 0,2\%), Mut (2 reakcje - 0,4\%), jednak doświadczanie jej jest źródłem rozmaitych, zdecydowanie pozytywnych odczuć i stanów, zarówno zmysłowych, jak i psychicznych, por. wybrane skojarzenia:

- w języku polskim: spokój (2 reakcje - 0,4\%), wewnętrzny spokój (1 reakcja $-0,2 \%)$, ciepto $(1$ reakcja $-0,2 \%)$, komfort $(1$ reakcja $-0,2 \%)$, poczucie wolności (1 reakcja $-0,2 \%)$, wolność (1 reakcja $-0,2 \%)$, radość (1 reakcja $-0,2 \%)$, spetnienie (1 reakcja - 0,2\%), uśmiech (1 reakcja - 0,2\%);

- w języku rosyjskim: спокойствие ( 2 reakcje $-0,4 \%$ ), лёгкость (1 reakсја $-0,2 \%)$, свобода (1 reakcja $-0,2 \%)$, стабильность (1 reakcja $-0,2 \%)$;

- w języku niemieckim: Erleichterung ( 1 reakcja - 0,2\%), reines Gewissen (1 reakcja - 0,2\%).

To (implicytne) dodatnio ukierunkowane wartościowanie prawdy znajduje potwierdzenie w pozostałych asocjatach waluatywnych. Są one werbalizowane z pomocą zarówno prymarnie, jak i wtórnie wartościujących środków językowych. Uznanie dla prawdy jako wartości zaznacza się szczególnie wyraźnie w ankietach niemieckojęzycznych - 10,2\% skojarzeń. Mniej odpowiedzi o charakterze oceniającym in plus przytaczają przedstawiciele polskiej społeczności studenckiej (6\% ogółu werbalizacji), najmniej zaś Rosjanie (4,6\% ujęzykowień). W katalogu skojarzeń waluatywnych pozytywnych znalazły się między innymi następujące reakcje:

- polskojęzyczne: czystość (5 reakcji - 1\%), podstawa (4 reakcje - 0,8\%), najważniejsza (3 reakcje - 0,6\%), wartość (3 reakcje - 0,6\%), bardzo ważna (1 reakcja - 0,2\%), ponad wszystko (1 reakcja - 0,2\%), priorytet (1 reakcja $-0,2 \%)$, przede wszystkim (1 reakcja - 0,2\%), wartość, o która warto walczyć (1 reakcja - 0,2\%);

- rosyjskojęzyczne: нужна (6 reakcji - 1,2\%), чистота (5 reakcji - 1\%), всегда (2 reakcje $-0,4 \%)$, хорошо (2 reakcje $-0,4 \%)$, лучше чаще (1 reakcja $-0,2 \%)$, юбой ценой (1 reakcja - 0,2\%), цель (1 reakcja - 0,2\%), это главное ( 1 reakcja $-0,2 \%)$;

- niemieckojęzyczne: wichtig (11 wskazań - 2,2\%), erstrebenswert (5 reakcji $-1 \%)$, Reinheit ( 2 reakcje $-0,4 \%)$, Tugend ( 2 reakcje $-0,4 \%)$, das Beste was es gibt (1 reakcja - 0,2\%), Grundlage ( 1 reakcja - 0,2\%), gut (1 reakcja - 0,2\%), Hauptsache (1 reakcja - 0,2\%), heilig (1 reakcja - 0,2\%), höchstes Gut (1 reakcja - 0,2\%), Priorität (1 reakcja - 0,2\%), sehr wichtig (1 reakcja $-0,2 \%)$, wofür es sich lohnt zu kämpfen (1 reakcja - 0,2\%).

Wartościowanie prawdy ma charakter dwuosiowy. Obok asocjatów waluatywnych dodatnich $\mathrm{w}$ odpowiedziach respondentów pojawiają się skojarzenia ukierunkowane in minus - najczęściej w ankietach rosyjsko- i niemieckojęzycznych (odpowiednio 6\% i 6,6\% ogółu werbalizacji), dwukrotnie rzadziej w ankietach polskich uczestników testu (3,2\% wszystkich wskazań), por. wybrane najbardziej charakterystyczne reakcje: 
- w języku polskim: bolesna ( 2 reakcje $-0,4 \%)$, gorzka ( 2 reakcje $-0,4 \%)$, trudna (2 reakcje $-0,4 \%)$, boli ( 1 reakcja $-0,2 \%)$, czasem boli (1 reakcja - 0,2\%), nieszczęście (1 reakcja - 0,2\%), smutek (1 reakcja - 0,2\%);

- w języku rosyjskim: горькая (9 wskazań - 1,8\%), глаза колет (4 reakсје $-0,8 \%)$, уши режет (3 reakcje $-0,6 \%)$, боль (1 reakcja $-0,2 \%)$, вред (1 reakcja $-0,2 \%)$, мало пользы (1 reakcja $-0,2 \%)$, молот (1 reakcja - 0,2\%), тяжесть (1 reakcja - 0,2\%);

- w języku niemieckim: kann weh tun (3 reakcje - 0,6\%), tut manchmal weh (3 reakcje $-0,6 \%)$, ist manchmal schmerzhaft ( 1 reakcja $-0,2 \%)$, kann hart sein (1 reakcja $-0,2 \%)$, manchmal schadet ( 1 reakcja $-0,2 \%)$, mächtiges Schwert (1 reakcja $-0,2 \%)$, nicht zu verkraften (1 reakcja - 0,2\%), Schmerz (1 reakcja $-0,2 \%)$, schmerzlich (1 reakcja $-0,2 \%)$, Stress ( 1 reakcja $-0,2 \%)$, tut oft weh (1 reakcja $-0,2 \%)$, tut weh (1 reakcja - 0,2\%).

Trudno jest zaś jednoznacznie rozstrzygnąć kierunek ewaluacji w modelu sprawczym prawdy osadzonym w odpowiedziach zwerbalizowanych przez 3,6\% Rosjan słowem cuлa (18 wskazań).

Niesprzeczne są natomiast niezbyt licznie obecne w ankietach poglądy odnośnie do faktu istnienia prawdy. Dwunastu ankietowanych Polaków (2,4\% respondentów), ośmiu Rosjan $(1,6 \%)$ i jedenastu respondentów zza zachodniej granicy $(2,2 \%)$ uważa, iż prawda jest wartością, która pojawia się zbyt rzadko, lub w ogóle neguje obecność prawdy, por.:

- asocjaty polskojęzyczne: nie istnieje (3 reakcje - 0,6\%), brak (2 reakcje - 0,4\%), nie ma prawdy (1 reakcja - 0,2\%), niemożliwa do poznania (1 reakcja - 0,2\%), nieosiagalność (1 reakcja - 0,2\%), poszukiwana (1 reakcja - 0,2\%), rzadko ujawniana w catości (1 reakcja - 0,2\%), trudna do osiagnięcia (1 reakcja $-0,2 \%)$, w tych czasach o nią ciężko (1 reakcja - 0,2\%):

- asocjaty rosyjskojęzyczne: редкость (5 reakcji - 1\%), её отсутствие (1 reakcja $-0,2 \%)$, редкая вещъ (1 reakcja $-0,2 \%)$, редко (1 reakcja - 0,2\%);

- asocjaty niemieckojęzyczne: selten (4 reakcje - 0,8\%), abstrakt (1 reakcja $-0,2 \%)$, gibt es nicht (1 reakcja $-0,2 \%)$, leider zu selten (1 reakcja $-0,2 \%)$, nicht erreichbar (1 reakcja - 0,2\%), schwierig zu erkennen (1 reakcja - 0,2\%), unmöglich (1 reakcja - 0,2\%), unbekannt (1 reakcja - 0,2\%).

Pozostałe reakcje nie są spójne $\mathrm{w}$ planie semantycznym i logicznym, stanowiąc przypuszczalnie echo silnie zindywidualizowanych doświadczeń ankietowanej młodzieży.

Zaskakuje stosunkowo niska pozycja prawdy w deklarowanym przez ankietowanych rankingu wartości. W hierarchii wyborów prawda umieszczana jest najwyżej przez polskich studentów i zajmuje ósme miejsce (60,6\% wskazań). Nieco mniej uznania wartość ta znajduje u badanych rosyjskojęzycznych, którzy przypisali jej miejsce dziewiąte $(28,4 \%$ wskazań), najrzadziej prawdą kierują się na co dzień młodzi Niemcy, sy tuując ją na odległej trzynastej pozycji (48\% wskazań). Różnica płci pociąga za 
sobą wahania $\mathrm{w}$ obrębie pozycji przypisywanej prawdzie $\mathrm{w}$ klasyfikacji hierarchicznej jedynie $\mathrm{w}$ badanej społeczności rosyjskojęzycznej, gdzie wyraźnie niższe wskaźniki odnotowano u kobiet - czternasta lokata (21,2\% wskazań).

\section{Bibliografia}

A r y s t o t e l e s, Metafizyka, tłum. K. Leśniak, Warszawa 1983.

C h 1 e b d a W., Płaszczyzny oglądu językowego obrazu świata, [w:] Komparacja systemów i funkcjonowania wspótczesnych języków stowiańskich I, red. S. Gajda, Opole 2000, s. 163-178.

Egzystencjalne i aksjologiczne wymiary prawdy, dobra i piękna, pod red. J. Gazdy i W. Morszczyńskiego, Kraków 2007.

F e r n á n d e z - A r m e s t o F., Historia prawdy, przekł. J. Ruszkowski, Poznań 1999.

G a j d a J., Wartości w życiu człowieka. Prawda. Miłość. Samotność, Lublin 1997.

G a l a r o w i c z J., Na ścieżkach prawdy, Kraków 1992.

$\mathrm{H}$ i $1 \mathrm{~d}$ e b r a n d D., Fundamentalne postawy moralne, tłum. E. Seredyńska, [w:] Wobec wartości, red. D. Hildebrand, J.A. Kłoczowski, J. Paściak, J. Tischner, Poznań 1982, s. 7-50.

Olb r y ch t K., Prawda, dobro i piękno w wychowaniu człowieka jako osoby, Katowice 2000.

R a r o t H., Sprawiedliwość jako prawda, [w:] Czy sprawiedliwość jest możliwa?, pod red. D. Probuckiej, Kraków 2008, s. 95-106.

R o d z i e w i c z B., Wartości. Polacy - Rosjanie - Niemcy, Szczecin 2014.

T o m a s z z A k w i n u, Kwestie dyskutowane o prawdzie, tłum. I. Kuczyński, t. 1, Kęty 1998.

W i e r z b i c k a A., Słowa klucze. Różne języki - różne kultury, Warszawa 2007.

Г а н е е в Б., Противоречия $в$ языке и речи, Уфа 2004.

Т а р а с о в Е.Ф., Актуальные проблемы анализа языкового сознания, [w:] Языковое сознание и образ мира, ред. Н. В. Уфимцева, Москва 2000, s. 24-32. 
